\title{
Cord presentation in labour: imminent risk of cord prolapse
}

\author{
Tiago Aguiar, ${ }^{1,2}$ João Cavaco Gomes, ${ }^{1}$ Teresa Rodrigues ${ }^{2}$
}

'Gynaecology Department, Centro Hospitalar Universitário São João, Porto, Portugal ${ }^{2}$ Obstetrics Department, Centro Hospitalar Universitário São João, Porto, Portugal

\section{Correspondence to} Dr Tiago Aguiar: tiagomdiasaguiar@gmail.com

Accepted 15 April 2021

\section{DESCRIPTION}

A 37-year-old pregnant woman at 39 weeks of gestation, gravida 3 , para 2, with a history of uncomplicated spontaneous vaginal deliveries at term, presented to the emergency department with lower abdominal cramps and watery vaginal discharge that started 2 hours before. Vaginal examination confirmed ruptured membranes, $3 \mathrm{~cm}$ cervical dilation, $30 \%$ effacement, and a mass of umbilical cord loops was presenting. Transvaginal ultrasound demonstrated an agglomerate of umbilical cord loops lying between the internal os and the fetal head (figures 1 and 2). Due to the imminent possibility of overt cord prolapse, an emergent caesarean section was performed, with the delivery of a newborn weighing $3640 \mathrm{~g}$, Apgar score 9 at $1 \mathrm{~min}$ and 10 at $5 \mathrm{~min}$.

Cord presentation (also known as funic presentation) is a rare condition with a reported incidence ranging from $0.006 \%$ to $0.16 \%$ in third trimester scans, ${ }^{1}$ and is defined as the presence of the umbilical cord between the fetal presenting part and the cervix, with or without intact membranes. ${ }^{2}$ To the best of our knowledge, no studies have addressed detection of this condition during labour, therefore, incidence and optimal management are not established. The main concern regarding cord presentation relates to an increased risk of cord prolapse and associated perinatal morbi-mortality. ${ }^{3}$

Suspicion may arise during vaginal examination but the diagnosis may not clear. Ultrasound can confirm the diagnosis by showing the presence of umbilical cord between the fetal presenting part and the cervix.

Spontaneous resolution by time of delivery can occur when the diagnosis is established during third trimester scan. However, the combination of ruptured

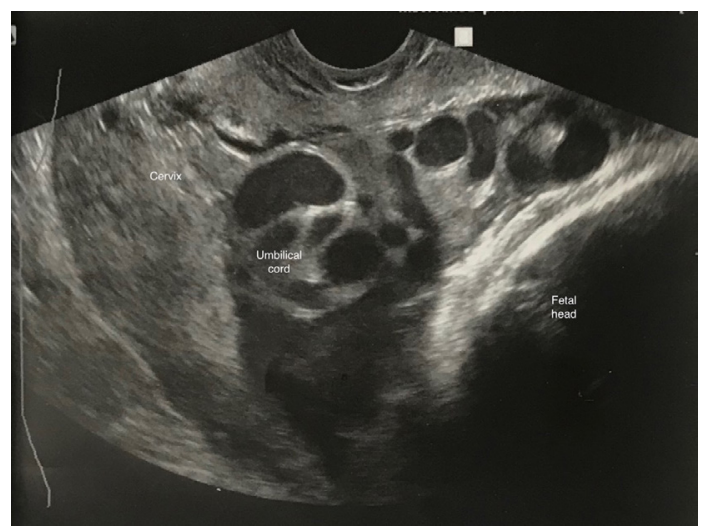

Figure 1 Transvaginal ultrasound showing the umbilical cord between the fetal head and the cervix.

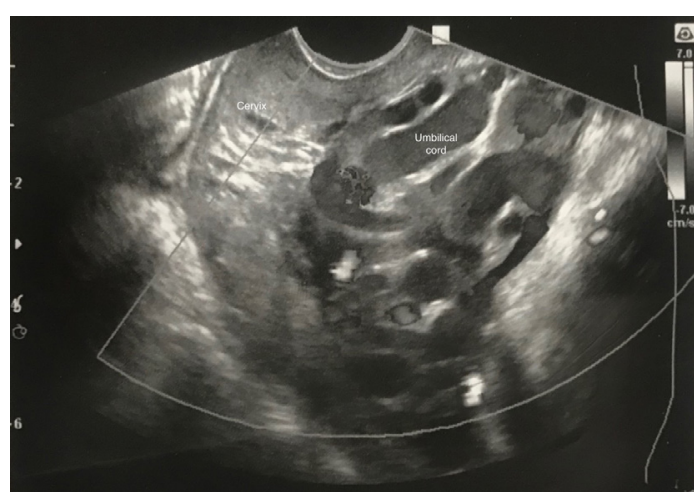

Figure 2 Transvaginal ultrasound showing loops of cord presenting above the internal cervical os. Flow confirmed with colour Doppler.

membranes and cord presentation during labour precedes an inevitable cord prolapse, as cervical dilation progress. Therefore, we agree with the majority of authors recommending caesarean section when funic presentation is found during labour. ${ }^{4}$

\section{Learning points}

- Cord presentation is a rare condition during labour, associated with imminent risk of cord prolapse.

- Diagnosis may be suspected during vaginal examination and is confirmed by ultrasound.

- Caesarean section is recommended when diagnosis is established during labour.

Contributors All authors were responsible for the diagnosis and management of the case reported. Dr TA was responsible for writing of the report. Dr JCG and Professor TR were responsible for the corrections before submission of the document.

Funding The authors have not declared a specific grant for this research from any funding agency in the public, commercial or not-for-profit sectors.

Competing interests None declared.

Patient consent for publication Obtained.

Provenance and peer review Not commissioned; externally peer reviewed.

\section{REFERENCES}

1 Ezra Y, Strasberg SR, Farine D. Does cord presentation on ultrasound predict cord prolapse? Gynecol Obstet Invest 2003;56:6-9.

2 Royal College of Obstetricians and Gynaecologists (RCOG). Umbilical cord prolapse. Green-top guideline No. 50. London: RCOG, 2014.

3 Mimura K, Endo M, Matsuzaki S, et al. Persistent funic presentation due to velamentous cord insertion adjacent to the internal os but not vasa previa. Taiwan J Obstet Gynecol 2020;59:167-8.

4 Jones G, Grenier S, Gruslin A. Sonographic diagnosis of funic presentation: implications for delivery. BJOG 2000;107:1055-7. 
Images in...

Copyright 2021 BMJ Publishing Group. All rights reserved. For permission to reuse any of this content visit https://www.bmj.com/company/products-services/rights-and-licensing/permissions/

BMJ Case Report Fellows may re-use this article for personal use and teaching without any further permission.

Become a Fellow of BMJ Case Reports today and you can:

- Submit as many cases as you like

- Enjoy fast sympathetic peer review and rapid publication of accepted articles

Access all the published articles

Re-use any of the published material for personal use and teaching without further permission

Customer Service

If you have any further queries about your subscription, please contact our customer services team on +44 (0) 2071111105 or via email at support@bmj.com.

Visit casereports.bmj.com for more articles like this and to become a Fellow 